\title{
Upaya Pengembangan Keprofesionalan Berkelanjutan MGMP IPA Kabupaten Batang melalui Pedampingan Penelitian Tindakan Kelas (PTK)
}

\author{
Muhamad Taufiq dan Wiyanto \\ Program Studi Pendidikan IPA, FMIPA Universitas Negeri Semarang, Indonesia \\ Email: muhamadtaufiq@mail.unnes.ac.id
}

\begin{abstract}
In the framework of coaching to become a professional teacher, needed Sustainable Development of Keprofesionalan (PKB). Development of sustainable profession is one of the main elements whose activities can be given credit numbers. While still often experienced constraints that occur when teachers make proposals and research reports in the making of background, theoretical basis, data collection techniques, data analysis even in the rules and others, as experienced by teachers members of Teachers Teachers Subject ( MGMP) IPA Kabupaten Batang. Teachers are still experiencing difficulties in making the design and implementation of PTK due to the limited ability of teachers and mentors who come from the Guiding Teacher. Activities in MGMP IPA SMP Batang District, as a container for the development of teacher competence, especially in making Research Action Class (PTK) is still not maximal. This dedication to the community aims to improve the ability of science teachers in planning, executing, reporting and publishing the results of PTK in scientific journals. Strategies used to achieve community service goals are training and mentoring the preparation of TOD for teachers members of MGMP IPA Batang District. Training and facilitation activities are conducted through the problem analysis phase, material presentation, discussion and at the end of the session are accompanied in planning, implementing and evaluating PTK activities. At the end of the activity the target teacher's devotion has resulted in PTK proposal and has knowledge of how to publish in scientific journal will be addressed.
\end{abstract}

Keywords: MGMP IPA, Batang District, Assistance of PTK

Abstrak. Dalam rangka pembinaan untuk menjadi guru yang profesional,
diperlukan Pengembangan Keprofesionalan Berkelanjutan (PKB). Pengembangan
keprofesian berkelanjutan merupakan salah satu dari unsur utama yang kegiatannya
dapat diberikan angka kredit. Sementara masih sering dialami kendala yang terjadi
disaat guru membuat proposal maupun laporan penelitian dalam pembuatan latar
belakang, landasan teori, teknik pengumpulan data, analisis data bahkan dalam
kaidah dan lain-lain, seperti halnya yang dialami oleh guru-guru anggota
Musyawarah Guru Mata Pelajaran (MGMP) IPA Kabupaten Batang. Guru-guru
masih mengalami kendala membuat rancangan maupun pelaksanaan PTK karena
keterbatasan kemampuan guru maupun pembimbing yang berasal dari Guru
Pemandu. Kegiatan di MGMP IPA SMP Kabupaten Batang, sebagai wadah 
pengembangan kompetensi guru, khususnya dalam pembuatan Penelitian Tindakan Kelas (PTK) masih belum maksimal. Pengabdian kepada Masyarakat ini bertujuan untuk meningkatkan kemampuan guru IPA dalam merencanakan, melaksanakan, melaporkan, serta mempublikasikan hasil PTK pada jurnal ilmiah. Strategi yang digunakan untuk mencapai tujuan pengabdian masyarakat ini yaitu pelatihan dan pendampingan penyusunan PTK bagi guru-guru anggota MGMP IPA Kabupaten Batang. Kegiatan pelatihan dan pendampingan dilakukan melalui tahap analisis masalah, paparan materi, diskusi dan pada akhir sesi dilakukan pendampingan dalam merencanakan, melaksanakan dan mengevaluasi kegiatan PTK. Pada akhir kegiatan pengabdian guru sasaran telah menghasilkan proposal PTK dan telah memiliki wawasan pengetahuan cara mempublikasikan pada jurnal ilmiah yang akan dituju.

Kata Kunci: MGMP IPA, Kabupaten Batang, Pendampingan PTK

\section{PENDAHULUAN}

Guru semakin dituntut untuk profesional oleh semua kalangan, namun terkadang tidak diikuti dengan fasilitas yang memadai sehingga dapat menimbulkan masalah. Dengan dikeluarkan Peraturan Bersama Mendiknas dan Kepala BKN Nomor 03/V/PB/2010 dan Nomor 14 Tahun 2010 tanggal 6 Mei 2010 tentang Petunjuk Pelaksanaan Jabatan Fungsional Guru dan Angka Kreditnya, disebutkan bahwa guru yang mau mengembangkan keprofesian yang berkelanjutan mulai dari kenaikan pangkat jabatan Fungsional Guru serendah-rendahnya Golongan III/b diwajibkan membuat Karya Inovatif berupa Penelitian, Karya Tulis Ilmiah, Alat Peraga, Modul, Buku, atau Karya Teknologi Pendidikan yang nilai angka kreditnya disesuaikan. Golongan IV/a ke golongan IV/b harus mempunyai sekurang-kurangnya 1 (satu) laporan hasil penelitian dan 1 (satu) artikel yang dimuat di jurnal yang ber-ISSN. Sementara di lapangan masih banyak kendala yang terjadi disaat guru membuat laporan sebuah penelitian terkadang dalam pembuatan latar belakang, di landasan teori, teknik pengumpulan data, analisis data bahkan dalam kaidah dan lain-lain, seperti halnya yang dialami oleh guruguru yang tergabung dalam Musyawarah Guru Mata Pelajaran (MGMP) IPA SMP Kabupaten Batang. MGMP merupakan organisasi profesi yang beranggotakan guru mata pelajaran di SMP/MTs dan SMA. MGMP IPA SMP Kabupaten Batang beranggotakan guru-guru IPA pada jenjang SMP, baik negeri maupun swasta yang berada di wilayah Kabupaten Batang. Organisasi MGMP IPA SMP Kabupaten Batang terdiri dari pengurus dan anggota. Pengurus MGMP terdiri dari ketua, sekretaris dan bendahara. Anggota MGMP terdiri dari guru mata pelajaran IPA dari SMP negeri dan swasta seKabupaten Batang yang berjumlah 175 yang berasal dari 15 SMP negeri dan 23 SMP Swasta, yang secara rinci tersaji dalam Tabel berikut. 
Tabel 1 Daftar Keanggotaan MGMP IPA SMP Kabipaten Batang Menurut Unit Kerja

\begin{tabular}{|c|c|c|c|c|c|}
\hline No. & Unit Kerja & $\begin{array}{l}\text { Jumlah } \\
\text { (Orang) }\end{array}$ & No. & Unit Kerja & $\begin{array}{l}\text { Jumlah } \\
\text { (Orang) }\end{array}$ \\
\hline 1 & SMP N 1 Batang & 3 & 38 & SMP N 2 Blado & 2 \\
\hline 2 & SMP N 2 Batang & 3 & 39 & SMP N 3 Blado & 1 \\
\hline 3 & SMP N 3 Batang & 4 & 40 & SMP N 4 Blado & 1 \\
\hline 4 & SMP N 4 Batang & 6 & 41 & SMP N 1 Bandar & 3 \\
\hline 5 & SMP N 5 Batang & 5 & 42 & SMP N 2 Bandar & 2 \\
\hline 6 & SMP N 6 Batang & 5 & 43 & SMP N 3 Bandar & 2 \\
\hline 7 & SMP N 7 Batang & 3 & 44 & SMP N 4 Bandar & 2 \\
\hline 8 & SMP N 8 Batang & 4 & 45 & SMP N 1 Wonotunggal & 3 \\
\hline 9 & SMP N 9 Batang & 2 & 46 & SMP N 2 Wonotunggal & 3 \\
\hline 10 & SMP N 1 Kandeman & 4 & 47 & SMP N 3 Wonotunggal & 1 \\
\hline 11 & SMP N 2 Kandeman & 3 & 48 & SMP N 1 Warungasem & 4 \\
\hline 12 & SMP N 3 Kandeman & 4 & 49 & SMP N 2 Warungasem & 4 \\
\hline 13 & SMP N 1 Tulis & 5 & 50 & SMP N 3 Warungasem & 2 \\
\hline 14 & SMP N 2 Tulis & 2 & 51 & SMP Muh. Tersono & 2 \\
\hline 15 & SMP N 1 Subah & 3 & 52 & SMP PGRI Gringsing & 1 \\
\hline 16 & SMP N 2 Subah & 2 & 53 & SMP Islam Subhanah & 1 \\
\hline 17 & SMP N 3 Subah & 1 & 54 & Subah & 1 \\
\hline 18 & SMP N 1 Banyuputih & 1 & 55 & SMP Al Ikhlas & 1 \\
\hline 19 & SMP N 1 Gringsing & 1 & 56 & Kandeman & 1 \\
\hline 20 & SMP N 2 Gringsing & 2 & 57 & SMP Cokroaminoto Batang & 1 \\
\hline 21 & SMP N 3 Gringsing & 5 & 58 & SMP Islam Batang & 1 \\
\hline 22 & SMP N 4 Gringsing & 2 & 59 & SMP Darul Ma'arif & 1 \\
\hline 23 & SMP N 1 Tersono & 4 & 60 & Banyuputih & 1 \\
\hline 24 & SMP N 2 Tersono & 2 & 61 & SMP An Nur Blado & 1 \\
\hline 25 & SMP N 3 Tersono & 2 & 62 & SMP El Husna Kandeman & 1 \\
\hline 26 & SMP N 1 Pecalungan & 4 & 63 & SMP Islam Al Charis & 1 \\
\hline 27 & SMP N 1 Limpung & 3 & 64 & Pecalungan & 1 \\
\hline 28 & SMP N 2 Limpung & 4 & 65 & SMP Islam Darul Hijrah & 1 \\
\hline 29 & SMP N 3 Limpung & 2 & 66 & Pecalungan & 1 \\
\hline 30 & SMP N 1 Bawang & 6 & 67 & SMP Ma'arif NU & 1 \\
\hline 31 & SMP N 2 Bawang & 1 & 68 & Banyuputih & 1 \\
\hline 32 & SMP N 3 Bawang & 3 & 69 & $\begin{array}{l}\text { SMP Miftahul Ulum } \\
\text { Cepokokuning }\end{array}$ & 1 \\
\hline 33 & SMP N 1 Reban & 4 & 70 & SMP A Yani Tulis & 1 \\
\hline 34 & SMP N 2 Reban & 4 & 71 & SMP Pondok Modern & 1 \\
\hline 35 & SMP N 3 Reban & 2 & 72 & Selamat Batang & 1 \\
\hline 36 & SMP N 4 Reban & 1 & 73 & $\begin{array}{l}\text { SMP Terpadu Al-Minhaj } \\
\text { Bandar }\end{array}$ & 1 \\
\hline 37 & SMP N 1 Blado & 4 & & & \\
\hline
\end{tabular}


Kegiatan peningkatan mutu MGMP IPA SMP Kabupaten Batang difasilitasi oleh Perkumpulan Pendidik IPA Indonesia Kabupaten Batang (PPII)Kabupaten Batang. PPII memiliki tata urutan/tingkat organisasi dari tingkat nasional, tingkat propinsi dan tingkat kabupaten/kota.PPII Kabupaten Batang merupakan organisasi profesi yang baru dibentuk pada tanggal 14 Desember 2016. Untuk mempermudah koordinasi, sebagian besar pengurus MGMP IPA SMP Kabupaten Batang juga menjadi pengurus PPII Kabupaten Batang.

Peningkatan profesionalitas guru IPA SMP di Kabupaten Batang dalam merencanakan, melaksanakan, melaporkan, dan mempublikasikan dalam bentuk artikel menjadi prioritas, bagi guru IPA guna mendukung keberlanjutan peningkatan mutu guru IPA selanjutnya. Sebagai khalayak sasaran (mitra) yang strategis dalam kegiatan pengabdian kepada masyarakat ini telah ditentukan 20 orang dari MGMP IPA SMP Kabupaten Batang Mereka adalah pengurus MGMP IPA SMP Kabupaten Batang serta beberapa anggota yang dinilai memiliki komitmen dan kemampuan untuk mengikuti kegiatan ini, serta mau dan mampu menularkan kepada anggota yang lain. Daftar Nama Mitra dengan pangkat golongan, pendidikan, serta kedudukan dalam MGMP disajikan pada Tabel 2 berikut.

Tabel 2 Daftar Nama Mitra Menurut Pangkat Golongan Ruang, Pendidikan, dan Jabatan dalam MGMP IPA SMP Kabupaten Batang

\begin{tabular}{cllcl}
\hline No. & \multicolumn{1}{c}{ Nama } & Pangkat/ Gol.Ruang & Pendidikan & \multicolumn{1}{c}{ Keterangan } \\
\hline 1 & Siti Qomsiyah, S.Pd & Penata/IIIc & S1 & \\
2 & Eko Dian Pratiwi, M.Pd & Pembina / IVa & S2 & $\begin{array}{l}\text { Bendahara } \\
\text { MGMP Rayon }\end{array}$ \\
3 & Erma Fatmawati, S.Pd & Penata / III c & S1 & \\
4 & Sri Umikarti, S.Pd & Pembina / IV a & S1 / Biologi & \\
5 & Bambang Triwibowo, S.Pd & Pembina / IV a & S1 Fisika & Ketua MGMP \\
& Kusniasih, S.Pd & Penata/IIIc & S1 Biologi & \\
6 & Tri Riswakhyuningsih, M.Pd & Penata TK.I/IIId & S2/Biologi & \\
7 & Purwaningsih, S.Pd & Pembina / IVa & S1 & \\
8 & Siti Komariyah, M.Pd & Pembina /Iva & S2/IPA & \\
9 & Sugiyono, S.Pd & Pembina / IV a & s1 & Kepala Sekolah \\
10 & Paimin, S.Pd Fis & Pembina /Iva & S1 & Ketua MGMP \\
11 & & Penata / IIIc & S1/Pertanian & Sub Rayon \\
12 & Retno Sulistyorini, S.Pi & Penata / IIIc & s1 & \\
13 & Ardi Wirawan, S.Pd & Pembina / Iva & s1 & \\
14 & Aliya Nurkhasanah, S.Pd & Penata / IIIc & S1 & \\
15 & Titiarti Hikmawati, S.Pd & Penata / IIIc & S1 & Sekretaris Sub \\
16 & Aris Suryani Putra, S.Si & Penata/IIIC & S1/Biologi & Rayon \\
& Sekretaris Sub \\
17 & Shanti Ardhini, S.Pd & & & Rayon \\
18 & Marjiyanti, S.Pd, M.Pd & PEMBINA/IVa & S2 & Kepala Sekolah \\
19 & Mokh. Darsono, S.Pd & Pembina Tk.I/IVb & S1/Fisika & Ketua MGMP \\
20 & Aziz Chakim, S.Pd & Penata Tk. I/III d & S1 Pend. Fisika & Rayon \\
& & & & MGretaris \\
& & & & \\
\hline
\end{tabular}


Berdasarkan permasalahan yang telah teridentifikasi dan setelah mengkaji potensi sumber daya alam dan sumber daya manusia, solusi yang ditawarkan dan telah disepakati bersama dengan mitra adalah kegiatan workshop dan pendampingan PTK inovatif bagi mitra. Penelitian Tindakan Kelas (PTK) merupakan salah satu jenis penelitian yang dapat dilakukan oleh seorang guru sebagai upaya guru merencanakan dan menghasilkan karya inovatif yang dapat dipublikasikan. PTK juga dimaksudkan untuk meningkatkan pencapain kompetensi siswa (Brantleyet al., 2007; Ferrance, 2000). Kegiatan di MGMP IPA SMP Kabupaten Batang merupakan salah satu upaya yang dilakukan untuk pengembangan kompetensi guru, khususnya dalam pembuatan Penelitian Tindakan Kelas (PTK) menjadi lebih maksimal. Workshop atau pelatihan berfokus pada penyusunan proposal PTK yang inovatif meliputi pembuatan latar belakang, landasan teori, teknik pengumpulan data, analisis data, kaidah dan cara mengakses jurnal ilmiah sebagai referensi dan tempat untuk mempublikasikan hasil PTK.

Pendampingan khusus untuk meningkatkan penyelenggaraan pelaksanaan kegiatan PTK IPA inovatif. Menurut Sarjita (2011) tujuan pendampingan terhadap guru untuk memberikan fasilitasi sebagai tindaklanjut dari permasalahan yang dialami oleh guru.Pendampingan oleh tenaga ahli, dapat memberikan dorongan bagi guru untuk berinovasi, dan sebagai media konsultasi untuk menemukan berbagai alternatif solusi permasalahan dalam melaksanakan PTK. Butin (2006) berpendapat bahwa fokus utama seorang pendamping adalah membantu terdamping dalam mengembangkan keterampilan profesional dalam suasana yang mendukung dan tidak menegangkan. Bentuk pendampingan yang terbaik terjadi sepanjang kurun waktu di mana kepercayaan, kerjasama, dan berbagi dibangun serta pertemuan rutin antara pendamping dan terdamping dijadwalkan. Pendampingan juga diprogramkan tidak hanya melalui temu tatap muka langsung, namun juga memanfaatkan fasilitas online yang memanfaatkan email maupun aplikasi sosial media (misal WA atau What's up juga $B B M$ ) yang mendukung dan memungkinkan terjalinnya komunikasi eifisien dan dan efektif.

Sesuai analisis kebutuhan tentang pentingnya dilakukan pendampingan PTK IPA inovatif, maka akan dilakukan kegiatan pendampingan dengan sasaran mitra. Pendampingan dilakukan agar mitra mampu dan kompeten dalam menyusun, melaksanakan dan mempublikasikan PTK melalui kemampuanpembuatan latar belakang, landasan teori, teknik pengumpulan data, analisis data, kaidah dan cara mengakses jurnal ilmiah sebagai referensi dan tempat untuk mempublikasikan hasil PTK dengan tahapan pendekatan saintifik.Kegiatan dilakukan melalui tahapan; pendalaman materi tentang PTK inovatif, pelatihan pembuatan latar belakang, landasan teori, teknik pengumpulan data, analisis data, kaidah dan cara mengakses jurnal ilmiah sebagai referensi dan tempat untuk mempublikasikan hasil PTK, pendampingan merencanakan, melaksanakan dan mengevaluasi kegiatan PTK inovatif.

Kemandirian dan inisiatif MGMP IPA SMP Kabupaten Batang sebagai mitra diwujudkan melalui upaya bekerja sama dengan LP2M UNNES sebagai impelemntasi Model MGMP Mandiri (Hidayah et al., 2015). Kemandirian MGMP yang memiliki sumber daya anggota, bekerjasama dengan LP2M UNNES dengan narasumber 
yangdibutuhkan akan mendukung implementasi Model KKG Mandiri dalam peningkatan dan penjaminan mutu guru berkelanjutan.

\section{METODE}

Kegiatan pelatihan dan pendampingan dilakukan di Sekretariat MGMP IPA SMP yang bertempat di SMP Negeri 4 Batang. Kegiatan workshop/pelatihan dan pendampingan ditempuh meliputi tiga tahapan yaitu; persiapan, pelaksanaan dan evaluasi. Kegiatan dilaksanakan dengan partisipasi dari mitra, serta dilakukan secara kolaborasi partisipatif tim pelaksana dan mitra, baik dalam tahapan persiapan, pelaksanaan, maupun tahap evaluasi.

1. Tahapan persiapan

Kegiatan dilaksanakan melalui tahapan sebagai berikut:

a. Koordinasi tim dosen pengabdian masyarakat dengan Ketua MGMP IPA SMP dan PPII Kabupaten Batang.

b. Pengiriman surat undangan kepada guru mitra oleh ketua MGMP IPA SMP Kabupaten Brebes sekaligus sebagai anggota mitra.

c. Penyusunan jadwal pelaksanaan pembimbingan, dilakukan bersama dengan mitra

d. Menyusun materi workshopPTK IPA inovatif bagi 20 guru mitra kegiatan oleh Tim pelaksana.

e. Menentukan topik penyusunan proposal PTKuntuk ditawarkan kepada guru mitra

f. Menyiapkan materi, alat dan bahan untuk kegiatan workshop dan pendampingan bersama mitra

2. Langkah-langkah pelaksanaan kegiatan berikut:

Tahapan pelaksanaan sebagai

a. Pre tes untuk mengukur pengetahuan awal guru mitra kegiatan tentang pengertian dan jenis-jenis PTK, serta tentang karya ilmiah.

b. Sosialisasi Model MGMP Mandiri sebagai model peningkatan mutu guru berkelanjutan kepada mitra.

c. Pendalaman materi tentang PTK, dilengkapi dengan informasi strategi pembuatan latar belakang, landasan teori, teknik pengumpulan data, analisis data, kaidah dan cara mengakses jurnal ilmiah sebagai referensi dan tempat untuk mempublikasikan hasil PTK. Kegiatan dilaksanakan dengan partisipasi aktif peserta (mitra) dalam bentuk tanya jawab dan diskusi

d. Pendampingan penyusunan tema dan atau judul PTK oleh mitra

e. Pendampingan pembuatan latar belakang, landasan teori, teknik pengumpulan data, analisis data, kaidah dan cara mengakses jurnal ilmiah sebagai referensi dan tempat untuk mempublikasikan hasil PTK oleh Tim.

f. Guru sasaran (mitra) didampingi tim dosen mempraktekkan pembuatan latar belakang, landasan teori, teknik pengumpulan data, analisis data, kaidah dan cara mengakses jurnal ilmiah sebagai referensi dan tempat untuk mempublikasikan hasil PTK.

g. Mendokumentasikan kegiatan.

h. Pos tes untuk mengukur keberhasilan pendampingan dalam menyusun proposal PTK.

i. Pelaksanaan PTK di sekolah masing-masing oleh mitra, diharapkan terjadi komunikasi antar anggota mitra selama melaksanakan PTK, sehingga permasalahan yang dihadapi dalam pelaksanaan PTK dapat diatasi. Disamping itu, akan dilakukan pendampingan secara periodik oleh Tim pelaksana. Pendampingan 
dilakukan sekaligus memfasilitasi mitra untuk mengatasi kendala yang mungkin dihadapi selama melaksanakan PTK dan menyusun laporan, serta artikel hasil PTK.

j. Seminar hasil PTK oleh mitra.

3. Rancangan Evaluasi

Evaluasi pelaksanaan kegiatan pengabdian masyarakat, secara rinci mekanisme evaluasi sebagai berikut;

1. Ketika pendalaman materi tentang konsep dan jenis PTK, dikumpulkan data melalui pre tes dan pos tes. Indikator keberhasilan $\geq 85 \%$ peserta pelatihan mendapatkan nilai 75.

2. Hasil pendampingan, guru mampu menghasilkan proposal PTK yang baik dan siap dilaksanakan berikut instrumennya dengan jumlah $100 \%$ dari jumlah yang telah disepakati bersama bersama mitra. Guru mampu melaksanakan PTK dan terampil mengakses laman jurnal untuk submit artikel pada jurnal atau seminar tertentu yang relevan dengan PTK yang dilakukan.

3. Minimal $80 \%$ dari judul PTK yang berhasil dilaksanakan siap diseminarkan dalam event MGMP.

\section{HASIL DAN PEMBAHASAN}

\section{Pelaksanaan Kegiatan}

Kegiatan pelatihan dan pendampingan telah dilaksanakan selama empat kali pertemuan pada tanggal 6 dan 20 April dan 5-6 Agustus tahun 2017. Peserta atau sasaran berasal dari SMP dan MTs yang ada di Kabupaten Batang dengan total peserta sebanyak 20 orang guru anggota MGMP IPA di Kabupaten Batang. Kegiatan pelatihan dan workshop Penelitian Tindakan Kelas (PTK) dengan tes pengetahuan awal guru sasaran tentang tentang pengertian dan jenis-jenis PTK, serta tentang karya ilmiah.
Berdasarkan analisis nilai tes pengetahuan awal, pengetahuan guru tentang PTK bervariasi dan rata-ratanya masih rendah yaitu rerata skor 56. Rerata skor kurang dari 75, dapat dikatakan sasaran belum memiliki pengetahuan yang baik tentang PTK.

Setelah diadakan tes awal terkait materi PTK pada kegiatan IbM dilanjutkan dengan paparan materi yaitu:

a. Sosialisasi Model MGMP Mandiri sebagai model peningkatan mutu guru berkelanjutan kepada mitra

$$
\text { Pada kegiatan ini materi }
$$
disampaikan oleh Dr. Isti Hidayah, M.Si Fasilitator SIPBM kerjasama UNNESUNICEF, Pusat Pengembangan Pengabdian KKN LPPM UNNES.Pada sesi ini disampaikan bahwa untuk dapat melaksanakan proses pendidikan sebagaimana diamanatkan oleh UUD 1945, maka di sekolah/madrasah diperlukan guru profesional. Dalam rangka pembinaan untuk menjadi guru yang profesional, maka diperlukan Pengembangan Keprofesionalan Berkelanjutan (PKB).

$$
\text { Berdasar Permenpan dan }
$$

Reformasi Birokrasi Nomor 16 Tahun 2009, Pengembangan Keprofesian Berkelanjutan adalah pengembangan kompetensi guru yang dilaksanakan sesuai dengan kebutuhan, bergradasi, dan berkelanjutan untuk meningkatkan profesionalitasnya. PKB dilakukan dapat dilakukan di sekolah/antar sekolah melalui kegiatan MGMP yang bersifat:

1) Relevan dengan aktivitas guru

2) Meningkatkan kemandirian guru dan sekolah

3) Mengurangi dampak negatif (guru sering meninggalkan sekolah)

4) Keterbatasan dana

5) Dampak pada lingkungan Tidak semua kebutuhan dapat dipenuhi di sekolah $\quad-$ terutama 
pengembangan penguasaan materi. $\mathrm{PKB}$ di luar sekolah dapat dilakukan dengan cara bersinergi dengan pihak luar sekoah yaitu LPTK.

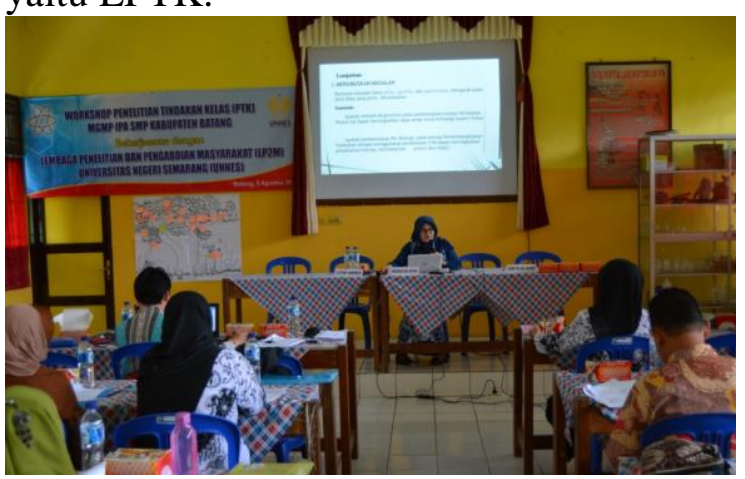

Gambar 1 Dr. Isti

Hidayah

menyampaikan materi

tentang pengembangan

MGMP Mandiri

\section{b. Workshop dan Pendampingan PTK}

Pada kegiatan ini disampaikan oleh Tim yang terdiri dari Muhamad Taufiq, M.Pd, Prof. Dr. Wiyanto, M.Si dan Prof. Dr. Sudarmin, M.Si. Workshop didahului dengan paparan pendalaman materi PTK dilengkapi dengan informasi strategi pembuatan latar belakang, landasan teori, teknik pengumpulan data, analisis data, kaidah dan cara mengakses jurnal ilmiah sebagai referensi dan tempat untuk mempublikasikan hasil PTK.Kegiatan dilaksanakan dengan partisipasi aktif peserta (mitra) dalam bentuk Tanyajawab dan diskusi.

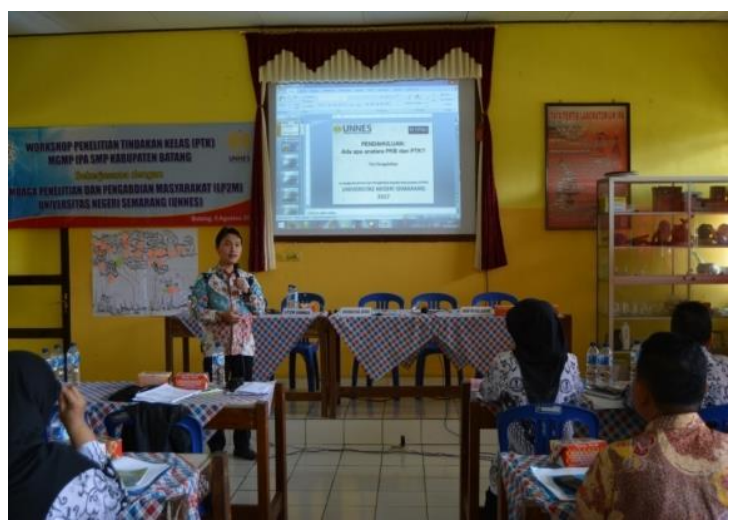

Gambar 2 Penyampaian materi cara mengakses jurnal
Pada saat pendampingan dilakukan oleh Tim pengabdian dengan memberikan saran dan masukan pada saat mitra melakukan penyusunan tema dan atau judul PTK oleh mitra, meliputi pendampingan: pembuatan latar belakang, landasan teori, teknik pengumpulan data, analisis data, kaidah dan cara mengakses jurnal ilmiah sebagai referensi dan tempat untuk mempublikasikan hasil PTK oleh Tim.Guru sasaran (mitra) didampingi tim dosen mempraktekkan pembuatan latar belakang, landasan teori, teknik pengumpulan data, analisis data, kaidah dan cara mengakses jurnal ilmiah sebagai referensi dan tempat untuk mempublikasikan hasil PTK.

c. Pos tes untuk mengukur keberhasilan pendampingan dalam menyusun proposal PTK.

Dari hasil pretes didapatkan skor rata-ratanya adalah 56.Skor tertinggi hasil pretesadalah 70 dan skor terendahnya adalah 40. Pada akhir kegiatan IbM pada sesi pelatihan dan workshop, selanjutnya dilakukan postes. Hasil analisis pemahaman dari pretes menunjukkan bahwa kebanyakan guru-guru masih bingung tentang mengidentifikasi jenis model-model PTK dan mengaplikasikannya dalam pembelajaran. Hasil postes menunjukkan hasil rerata skor 95, dengan skor tertinggi 100 dan terendahnya adalah 80 . Setelah paparan dan pendampingan kesulitan dan pemahaman guru-guru sasaran meningkat, termasuk terkait mengidentifikasi model-model PTK dan menyusun proposal PTK untuk dilakukan di kelas masing-masing.

Hasil tersebut menunjukkan bahwa kegiatan pelatihan dan workshop telah berhasil meningkatkan pemahaman guruguru sasaran tentang PTK. Hal ini ditunjukkan dari hasil rata-rata maupun skor individu para guru sasaran yang telah 
mencapai $\geq 85$. Ketercapaian keberhasilan klasikal juga sangat bagus, karena $\geq 80 \%$ pesertaguru-gurusasaran tuntas dalam penyusunan proposal PTK .Sementara itu terkait efektivitas kegiatan pengabdian maka dihitung gain atau peningkatan pengetahuan peserta yaitu rerarata gainnya adalah 0,88 pada kategori tinggi menurut kriteria gain Hake.

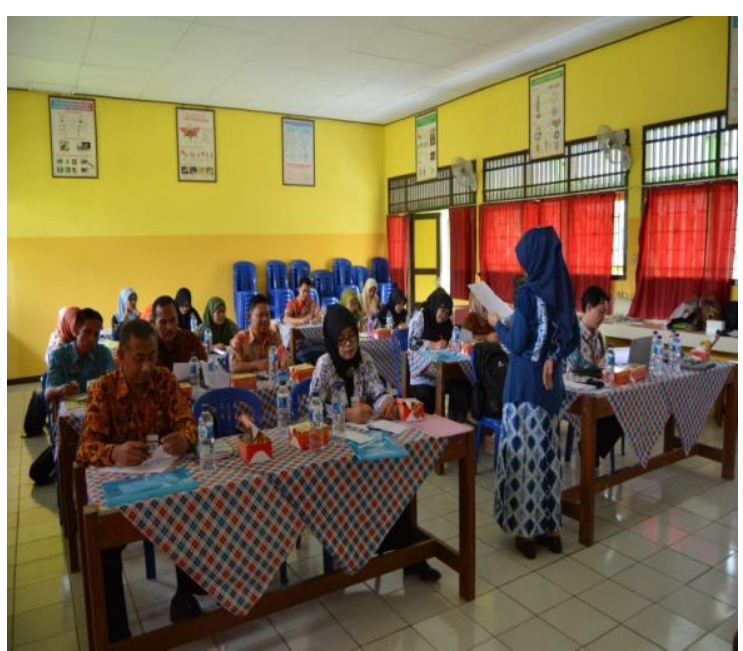

Gambar 3. Peserta mengerjakan postes

Selanjutnya dilakukan kegiatan pendampingan pelaksanaan PTK di sekolah. Kegiatanini ditujukan untuk memberikan fasilitasi sebagai tindaklanjut dari permasalahan yang dialami oleh guru. Pendampingan oleh tenaga ahli, dapat memberikan dorongan bagi guru untuk berinovasi, dan sebagai media konsultasi untuk menemukan berbagai alternatif solusi permasalahan dalam melaksanakan PTK. Bentuk pendampingan yang terbaik terjadi sepanjang kurun waktu di mana kepercayaan, kerjasama, dan berbagi dibangun serta pertemuan rutin antara pendamping dan terdamping dijadwalkan. Pendampingan tidak hanya melalui temu tatap muka langsung, namun juga memanfaatkan fasilitas online yang memanfaatkan email maupun aplikasi sosial media (misal WA atau What's up juga $B B M$ ) yang mendukung dan memungkinkan terjalinnya komunikasi eifisien dan dan efektif.

\section{Refleksi dan Analisis Ketercapaian Tujuan Kegiatan Pengabdian}

Peserta sangat antusias mengikuti kegiatan,kehadiran dosen-dosen pendidikan IPA sebagai fasilitator sangat membantu dalam membantuguru sasaran. Fasilitator juga terlibat diskusi dengan guru sasaran, diantaranya tentang kesulitan pengimplementasian dan pelaksanaan PTK. Namun setelah didampingi dan diberi penejelasan guruguru sasaran merasalebih percayadiri.

Evalusi kegiatan dilaksanakan dari awal kegiatan sampai pada akhir kegiatan. Untuk merekam pendapat peserta terkait pelaksanaan IbM dari awal sampai akhir diambil datamenggunakan angket dengan pertanyaan dan hasil sebagai berikut:

Tabel 8 Respon peserta terhadap pelaksanaan kegiatan IbM

\begin{tabular}{llrrrr}
\hline No & $\begin{array}{l}\text { Respon pelaksanaan kegiatan } \\
\text { sosialisasi/pelatihan penilaian } \\
\text { autentik }\end{array}$ & $\begin{array}{l}\text { Respon } \\
\text { peserta }\end{array}$ & dari & total & 20 \\
& & 4 & 3 & 2 & 1 \\
\hline 1 & $\begin{array}{l}\text { Saya memahami materi yang } \\
\text { disampaikan penyaji kegiatan workshop } \\
\text { PenelitianTindakanKelas (PTK) }\end{array}$ & 19 & 1 & 0 & \\
\hline
\end{tabular}




\begin{tabular}{|c|c|c|c|c|c|}
\hline 2 & $\begin{array}{l}\text { Saya mendapatkan informasi yang jelas } \\
\text { tentang tujuan PTK }\end{array}$ & 20 & 0 & 0 & 0 \\
\hline 3 & $\begin{array}{l}\text { Saya memahami prinsip dan karakteristik } \\
\text { PTK }\end{array}$ & 18 & 2 & 0 & 0 \\
\hline 4 & $\begin{array}{l}\text { Saya memahami model-model dan } \\
\text { prosedur pelaksanaan PTK }\end{array}$ & 18 & 2 & 0 & 0 \\
\hline 5 & $\begin{array}{l}\text { Bahan materi workshop disajikan dengan } \\
\text { baik. }\end{array}$ & 20 & 0 & 0 & 0 \\
\hline 6 & $\begin{array}{l}\text { Paparan disajikan dengan media yang } \\
\text { memadai }\end{array}$ & 20 & 0 & 0 & 0 \\
\hline 7 & $\begin{array}{l}\text { Penyaji memberikan informasi dengan } \\
\text { jelas, runtut, sistematis, dengan contoh- } \\
\text { contoh yang relevan. }\end{array}$ & 20 & 0 & 0 & 0 \\
\hline 8 & $\begin{array}{l}\text { Setelah mengikuti workshop ini } \\
\text { dapat maa } \\
\text { pembelajaran IPA di tempat } \\
\text { bekerja. }\end{array}$ & 20 & 0 & 0 & 0 \\
\hline 9 & $\begin{array}{l}\text { Saya mendapatkan manfaat yang berarti } \\
\text { dari kegiatan sosialisasi/ pelatihan } \\
\text { pembelajaran IPA berbasis kearifan lokal } \\
\text { ini }\end{array}$ & 20 & 0 & 0 & 0 \\
\hline 10 & $\begin{array}{l}\text { Saya berharap ada pendampingan } \\
\text { publikasi PTK ataun tindak lanjut }\end{array}$ & 20 & 0 & 0 & 0 \\
\hline
\end{tabular}

Keterangan:SS= SangatSetuju (4), S= Setuju (3), TS=TidakSetuju (2), dan STS= Sangat Tidak Setuju(1)

Evalusi kegiatan dilaksanakan dari awal kegiatan sampai pada akhir kegiatan. Untuk merekam pendapat peserta terkait pelaksanaan kegiatan IbM dari awal sampai akhir diambil data menggunakan angket. Sebanyak 18 dari 20 peserta merasa sangatpaham, 2 dari 20 peserta paham terkait prinsip dan model-model PTK. Terkait dengan tindak lanjut kegiatan seluruh peserta guru sasaran sangat setuju untuk diadakan kegiatan sejenis pada waktu-waktu selanjutnya.

\section{SIMPULAN DAN SARAN}

Upaya Pengembangan Keprofesionalan Berkelanjutan MGMP IPA Kabupaten Batang melalui Pedampingan Penelitian Tindakan Kelas (PTK) telah dilaksanakan dan dapat disimpulkan sebagai berikut:

1. Pelatihan dan workshop PTK pada guru IPASMP/MTs di Kabupaten Batang yang dilakukan mendapat respon positif dari guru dalam mendukung publikasi ilmiah dan karya inovatif.

2. Guru sasaran telah memiliki wawasan tentang PTK yang baik dan mitra telah mampu menyusun proposal PTK sesuai dengan kaidah yang baik.

Saran yang dapat diberikan yaitu:

1. Pendampingan harus selalu diprioritaskan untuk dilakukan setelah kegiatan pelatihan maupun workshop

2. Kegiatan pendampingan terhadap guru perlu selalu mengedepankan asas kolegalitas dan kesejajaran 
karena akan berdampak pada keberhasilan selama kegiatan.

Guru sasaran sangat mengharapkan kegiatan sejenis pada waktu-waktu yang akan datang dan tidak terbatas masalah PTK,tetapi pada aspek yang lain misalnya Evaluasi autentik dan Perangkat Kurikulum 2013 khususnya materi IPA terpadu.

\section{DAFTAR PUSTAKA}

Brantley, H., Barron, L., Hicks, G. C., \& McIntyre, L. (2007). An Action Research Model: Using Dispositions to Enhance the Diverse Classroom Practices of Inservice and Pre-service Teachers. Teacher Education Journal of South Carolina , 75-83.

Butin W. 2006.Introduction Future Directions for Service Learning in Higher Education.International Journal of Teaching and Learning in Higher Education.18 (1): 1-6.

Ferrance, E. (2000). Action research.Providence, RI: Brown University.

Hidayah, I., Pristiwati, R., dan Widiyatmoko, A.2015. Kajian kesiapan guru mata pelajaran Matematika, Bahasa Indonesia, dan IPASMPdalam implementasi kurikulum 2013 di Kota Semarang. Jurnal Penelitian Pendidikan. 32 (2), 127-136.

Sarjita, A. 2011.Pendampingan Pasca Pelatihan Guru Program Prioritas. ModulProgram Prioritas.DBE 3 USAID. 
Rekayasa Vol. 16 No.2, Desember 2018 